\section{Entrepreneurship and Human Development: An International Analysis}

\author{
José Antonio Camacho Ballesta ${ }^{1}$ \\ ${ }^{1}$ Department of Spanish and International Economics, University of Granada, \\ Granada-Spain
}

Bladimir José de la Hoz Rosales ${ }^{2}$

${ }^{2}$ Economics Program, University of Magdalena, Santa Marta - Colombia

Ignacio Tamayo Torres $^{3}$

${ }^{3}$ Management Department, University of Granada, Granada - Spain
Received on:

03/06/2019

Approved on:

04/06/2020

\section{Responsible Editor:}

Prof. Dr. João Mauricio Gama

Boaventura

\section{Evaluation process:}

Double Blind Review

\title{
Abstract
}

Purpose - This study aims to analyze the impact on human development of rates of innovative entrepreneurship and necessity entrepreneurship.

Design/methodology/approach - Our empirical study is based on samples from countries with information about rates of entrepreneurship, human development, and social progress. The data are analyzed by means of pooled least squares and panel data techniques.

Findings - Innovative entrepreneurship improves the quality of life in the dimensions measured by the Social Progress Index and Modified Human Development Index. Necessity entrepreneurship does not favor an increase of human development, at least in the dimensions measured by the two indexes, since this is a subsistence entrepreneurship type.

Originality/value - This study presents new evidence that contributes to the knowledge on how entrepreneurship improves quality of life.

Keywords - human development, innovative entrepreneurship, necessity

entrepreneurship, capability approach. 


\section{Introduction}

Social science academics have historically been motivated to study entrepreneurship (Urbano, Aparicio, \& Audretsch, 2018). Research on the effects of entrepreneurship has focused primarily on determining its impact on economic growth, productivity, and employment (Acs \& Szerb, 2007; Campos, Parellada, \& Palma, 2012; Carree, Van Stel, Thurik, \& Wennekers, 2007; Perényi \& Losoncz, 2018). Interest in understanding the effects of entrepreneurship on the economy grew at the beginning of the 1980s, when a study of job creation in the United States by Birch (1981) concluded that small and mediumsized enterprises were the main agents creating employment (Gnyawali \& Fogel, 1994; Urbano \& Alvarez, 2014).

Since the last decade of the 20th century, research about the social effects of entrepreneurship has focused on determining its impact on countries' development, from the perspectives of economic and regional development. The results of these studies have concluded that the social impact of entrepreneurship depends primarily on factors such as a country's stage of development, the economic sector in which the entrepreneurial activity is performed, and the motivations that lead people to become entrepreneurs (Acs, Audretsch, Braunerhjelm, \& Carlsson, 2012; Acs \& Storey, 2004; Audretsch, 2007; Audretsch, Bönte, \& Keilbach, 2008; Urbano $\&$ Aparicio, 2016). The type of entrepreneurship that generates the greatest impact on economic growth and economic development is opportunity entrepreneurship oriented toward innovation (Acs et al., 2012; Acs \& Storey, 2004; Baumol, 1990; Levie, Autio, Acs, \& Hart, 2014; Schumpeter, 1939; Shane \& Venkataraman, 2000; Wennekers, Van Wennekers, Thurik, \& Reynolds, 2005).

However, theories of development have been extended to include alternative arguments to those that support economic growth as a driver of societal wellbeing (Kleine, 2010). Since the second half of the 20th century, discussions of development have been guided by different perspectives. These include theories positing the origin of dependency and inequalities as characteristics of the capitalist system (Frank, 1967), and alternative approaches to development that recognize ecological, economic, and social goals (Chambers, 1983). One of the most influential theories countering the view of development focused on economic growth is the capability approach (CA) (Kleine, 2010; Robeyns, 2005). In this approach, development is defined as "a process of expanding the freedoms that people enjoy" (Sen, 1999, p. 3) to lead the kind of life they have reason to value (Sen, 1999). In this theory, economic growth is important only as a means for people to achieve and live lives that they value (Drèze \& Sen, 2002; Robeyns, 2005).

Growing interest in a human development paradigm grounded primarily in the CA (Robeyns, 2017) has led to the need to research the effects of entrepreneurship on the expansion of capabilities or human freedoms (Hartmann, 2014; Naudé, Amoros, \& Cristi, 2013). Since 1990, the CA has been used as a theoretical framework for the universal promulgation of the concept of HD (UNDP, 1990). This concept includes the expansion of people's capabilities so that political, economic, and social freedoms provide them with "opportunities for being creative and productive" (UNDP, 1990, p. 10). This definition highlights the need for people to develop their creativity, which motivates them to innovate in the production of goods and services, potentially approaching the concept of the entrepreneur suggested by Schumpeter (1939). The UN's vision of the impact of entrepreneurship on HD is observed in the reports it has issued. The review shows a close relationship between entrepreneurship and HD, with the 2015 report in particular highlighting the benefits of creative entrepreneurship and innovation, which may have a positive impact on society (UNDP, 2014).

However, few studies published in high-impact journals provide information on the relationship between entrepreneurship and HD. One important contribution is made by Gries and Naudé (2011), who proposed a theoretical framework that could relate entrepreneurship to HD based on the CA approach. For these authors, entrepreneurship is a "functioning," because it is the result of the economic or work activity in which people are involved. They argued that entrepreneurship, as a resource, has the capacity to generate new job opportunities in addition to facilitating other functionings.

A literature review by Gries and Naudé (2011) concluded that few studies have been published about the impact of entrepreneurship on development beyond its contribution to economic growth, highlighting the need for evidence to address this gap. In the review carried out for this study, Gries and Naudés (2011) conclusion is validated. Therefore, the main goal of this study is to present new evidence about the relationship between entrepreneurship and human development (HD). This analysis is carried out using the CA as the theoretical framework, which implies that to determine the effects 
of entrepreneurship on HD, the analysis should first identify whether entrepreneurs engage in an activity because it is what they really want to do, or because it is imposed on them by their socio-economic circumstances. Then, the analysis should focus on the normative aspect of entrepreneurship by identifying whether this type of activity positively or negatively affects HD. Therefore, it is necessary to evaluate the relationship between entrepreneurship rates and multidimensional measures of human development.

An econometric analysis is carried out using the pooled ordinary least squares (pooled OLS) and panel data techniques. The results provide new evidence on the effects of entrepreneurship on HD. The findings suggests that innovative entrepreneurship has a positive effect on HD, measured by the Social Progress Index (SPI), which is calculated based on 53 indicators classified into three dimensions of social progress: basic human needs, foundations of wellbeing, and opportunity. Furthermore, innovative entrepreneurship has positive effects on the Modified Human Development Index (MHDI), without gross domestic product per capita. However, the results indicate that necessity entrepreneurship does not help to increase human development, whether measured by the SPI or MHDI.

The rest of the paper proceeds as follows. The next section presents the conceptual framework and develops the hypotheses. Section 3 outlines the sources of information and method. Section 4 presents the findings. The final section concludes the paper with recommendations and policy implications.

\section{Conceptual Framework and Hypotheses}

\section{I. Capability approach (CA) and entrepreneurship}

Historically, GDP per capita has been used to measure development (Kuznets, 1955). However, researchers have recognized that pure economic indicators do not represent the full multidimensionality of development (Stiglitz, Sen, \& Fitoussi, 2009). S. Anand and Sen (2000) argued that focusing on variables such as GDP per capita or national wealth to measure levels of development perpetuates the traditional approach oriented toward opulence, whereas the search for wellbeing should focus on improvements in positive freedoms or people's capabilities (Sen, 1999).
The CA is a better way to measure inequality based on its multidimensionality. Sen's contribution to creating an alternative measure of improvement in quality of life has made him one of the main theoreticians of human development. For Sen, development is associated with people's capability to live the kind of lives that they value (Sen, 1999).

The philosophical thinking of the CA provides the basis for creating the human development paradigm, which seeks to redirect the discussion about the concept of wealth toward what people are able to do or be. The CA differs from the utilitarian approach, which explains people's level of satisfaction based on the amount of goods and services that enable them to have a particular lifestyle (Fukuda-Parr, 2003; Robeyns, 2017). CA analysis is based on the concepts of capabilities, functioning, and agency (Alkire, 2005; Robeyns, 2017; Sen, 1998, 2005; Sugden $\&$ Sen, 1986). Capabilities are what people are free to do, functioning is what people actually do (P. Anand et al., 2009), and agency is people's ability to pursue the goals they set voluntarily. A person without agency performs crucial activities in life as an obligation (Alkire, 2005).

Notably, before analyzing functionings from a normative perspective, the CA suggests that their neutrality be recognized, which refers to the action (functioning) of generating results, which can be valued positively or negatively. Therefore, if an action is evaluated negatively, it is not excluded as a functioning (Robeyns, 2017). Accordingly, the analysis of entrepreneurship as a functioning implies recognizing its neutrality; in other words, being an entrepreneur does not depend on the impact of the business on society, but on the action of creating a new business itself. Once the entrepreneurial action has taken place, the person who carries it out and society establish value judgments about its expediency

Gries and Naudé (2011, p. 217) defined entrepreneurship as "the resources, processes, and state of being through and in which individuals utilize positive opportunities in the market by creating and growing new business firms." This definition is normative in the CA framework because it values or validates only entrepreneurial activities that have a positive impact on quality of life.

The GEM classifies entrepreneurs into different types according to their motivations for becoming entrepreneurs (opportunity vs. need) and type of economic activity (Reynolds et al., 2005). Based on the recognition of the conceptual neutrality of functionings, necessity entrepreneurship is a functioning. Opportunity 
entrepreneurship, especially innovative entrepreneurship, contributes to economic growth and job creation (Acs \& Storey, 2004; Audretsch, 2012; Bosma et al., 2017; Reynolds, 2017; Schumpeter, 1939; Shane \& Venkataraman, 2000; Urbano, Aparicio, \& Querol, 2016; Wennekers et al., 2005). Innovative entrepreneurship possesses the characteristics closest to the concept of entrepreneur adopted in this study, because such entrepreneurs have (i) the necessary economic and non-economic resources to be transformed into innovative products or services; (ii) the necessary skills and knowledge to manage their business activities; and (iii) the necessary freedom to transform the resources and bring them to the market as final goods or finished products. At this point, entrepreneurs can use their liberties to create a new firm, because it is allowed under the structural restrictions; and (iv) there is the recognition of this action as a functioning. Furthermore, they have (v) agency because creating a new enterprise is a voluntary act that allows entrepreneurs to fulfil their goal of achieving the life they desire. The result of this action generates a positive social impact, as it creates new employment options and new goods or services to cater for the needs of others.

Thus, this conceptualization implies that opportunity-oriented entrepreneurial activities aimed at innovation contribute significantly to social progress. This leads to the following hypothesis:

H1: The contribution of innovative entrepreneurship to human development extends beyond the generation of monetary income to the expansion of capabilities so that people can live the lives they really desire.

Necessity entrepreneurship can be considered as a functioning. However, its assessment from the normative perspective cannot be extended beyond the definition, that is, a means of subsistence for the person performing it (Reynolds et al., 2005) and probably for his or her family circle. The results of some studies on the impact of being an entrepreneur out of necessity indicate that when a person is obliged to perform an activity as the sole option for subsistence, it restricts his or her agency, which can cause dissatisfaction, because he or she is unable to (exercise his or her free will and) do what he or she really desires (Binder \& Coad, 2016; Block, Kohn, Miller, \& Ullrich, 2015).

Similarly, according to Harbi and Grolleau (2012), the advantages of a person working on his or her own account include achieving independence and flexibility of time. However, when the individual is working on his or her own account involuntarily, in evaluating the results of the activity, the negative impacts outweigh the positive. Thus, necessity entrepreneurship has a questionable impact on people's happiness. Furthermore, according to Gries and Naudé (2011), necessity entrepreneurship restricts human agency, because it is solely a means of subsistence for the person who performs it.

Sen argues that an agent is "someone who acts and produces a change, and whose achievements can be judged in terms of his own values and objectives, whether or not we evaluate them based on some external criteria as well" (Sen, 1999, p. 19). According to Alkire (2005), the definition of the role of Sen's agency extends beyond most definitions of empowerment, as agency is exercised with respect to multiple objectives; it includes effective power, as well as direct control; it can be aimed at achieving individual and collective wellbeing; it implies an assessment of the value of the objectives for which an action is carried out; and it introduces the need to incorporate the agent's responsibility.

Analyzing the agency in necessity entrepreneurship implies inserting the person responsible for this activity into Sen's definition of agency, observing that he or she fulfils the first part, that is, acts and produces changes, but whose achievements may be judged only as the most basic goal of any human being, that is, to subsist, whereas the other goals related to living the life he or she really desires are beyond his or her reach.

Therefore, it could be inferred that necessity entrepreneurship is an activity that implies an action and produces changes but restricts people from leading the lives they really desire. This implies the second hypothesis: $\mathrm{H} 2$ : Necessity entrepreneurship restricts the expansion of human capabilities for a person to be able to lead the life he or she really desires.

\section{Materials and Methods}

\section{I Materials}

\section{I.I Dependent variables}

Since the UNDP accepted the human development paradigm in 1990, the organization has created the Human Development Index (HDI), composed of the following three dimensions: a decent level of living (measured by gross domestic product per capita); a long and healthy life (measured by life expectancy at birth); 
and access to knowledge (expected years of schooling). However, the objective of this study is to provide new evidence on the effect of entrepreneurship on human development, beyond its contribution to the generation of monetary income. Furthermore, GDP per capita is not a real measure of income level (Stiglitz et al., 2009). Therefore, a modification was made to the HDI, which involved suppressing the decent level of living dimension. Thus, the MHDI includes the dimensions of a long and healthy life and access to knowledge, both of which have equal weight, that is, 50/50.

The MHDI in this study is also used by Dhahri and Omri (2018) to test the contribution of entrepreneurship to sustainable development. Similarly, Costantini and Monni (2008) employ the same modification to analyze the relationship between the environment, human development, and economic growth.

Taking into account that the MHDI has only two dimensions, in order to have more information on the incidence of entrepreneurship in human development, we use a second dependent variable, the SPI. Created in 2013 by the non-profit organization Social Progress Imperative Foundation, the first version of the SPI was created under the leadership of Michael Porter at Harvard University and Scott Stern at the Massachusetts Institute of Technology as a tool to measure quality of life and an alternative to the HDI. In 2015, after discussions with experts from around the world on the shortcomings of using GDP per capita as an indicator of development (Porter, Stern, \& Artavia Loría, 2013; Stern, Wares, \& Epner, 2017), the foundation launched a new version of the SPI. Based on the theoretical concepts of development formulated by Douglas North, Joseph Stiglitz, and Amartya Sen (Porter et al., 2013), the SPI was defined by a group of experts belonging to the Social Progress Imperative Foundation as follows:

The capacity of a society to meet the basic human needs of its citizens, establish the building blocks that allow citizens and communities to enhance and sustain the quality of their lives, and create the conditions for all individuals to reach their full potential (Stern et al., 2017, p. 3).

The SPI is structured into three elements: dimensions, components, and indicators. The dimensions are the three sub-indexes (Basic Human Needs, Foundations of Wellbeing, and Opportunity). Each dimension is composed of four components, and each component is composed of indicators. The indicators are aggregated to each component through exploratory factor analysis, using principal component analysis (Stern, Wares, Orzell, \& O'Sullivan, 2014). Appendix A presents the full structure of this index.

The SPI has been used in other studies that have attempted to explain the causes and effects of various processes of human interaction in relation to improving quality of life (Asandului, Iacobuta, \& Cautisanu, 2016; Lo, Ash-Houchen, \& Gerling, 2017; Mattedi, Bazanela, Santos, \& Pereira, 2015; Mayer, Haas, \& Wiedenhofer, 2017). The SPI has been the subject of validation analysis, where the results indicated that it is one of the indexes with the highest number of indicators for measuring improvements in people's quality of life based on different dimensions. Its calculation method rests on strong theoretical foundations. The main limitation is the short period of time used, which prevents comparative studies from showing changes in countries in the medium and long term (Stanojević \& Benčina, 2018).

\subsection{Independent variables}

Total Entrepreneurial Activity by Innovation (TEAIN) is measured as the percentage of all people surveyed who are involved in the total entrepreneurial activity rate (TEA) and who report that their product or service is novel for at least some of their customers and that few or no companies offer the same product. TEA represents the percentage of the active population who are either nascent entrepreneurs or owner-managers of a new business and comes from the Adult Population Survey (APS) published by the GEM (Bosma et al., 2017). TEAIN has a scale from 0 to 100 .

The APS is administered in approximately 100 countries through stratified sampling by gender and age taking into account the active population (people aged 18 to 64 years old). The GEM usually provides 95 percent confidence intervals for the estimates reported in its global reports (Bosma et al., 2017). The GEM is ranked as the most important study of entrepreneurship globally. The UN, World Bank, Organization for Economic Co-operation and Development, and World Economic Forum, among other bodies, use its information to propose policies to support entrepreneurship all over the world (Reynolds, 2017). Moreover, GEM data currently constitute the main source of information for conducting empirical 
studies that attempt to explain the causes and effects of entrepreneurship (Urbano \& Alvarez, 2014).

Several studies have used TEAIN to determine the relevance of innovation entrepreneurship for economic growth and development (Szabo \& Herman, 2012); the relationship between entrepreneurship and the business cycle (Koellinger \& Thurik, 2012); the influence of social progress on innovative entrepreneurship (Aparicio, Urbano, \& Audretsch, 2016), and the relationship between leadership styles and innovative entrepreneurship (Van Hemmen, Alvarez, Peris-Ortiz, \& Urbano, 2015).

Total Entrepreneurial Activity by Necessity (TEANEC) is measured as the percentage of all respondents involved in TEA who report undertaking the activity out of necessity due to there being no other work option (Reynolds et al., 2005). This variable has been used to demonstrate its impact on economic growth, as well as its relationship with institutional variables (Acs, 2006; Borozan, Arneric, \& Coric, 2017; Hechavarria \& Reynolds, 2009; Rosa, Kodithuwakku, \& Balunywa, 2008; Urbano, Aparicio, \& Querol, 2016).

\section{I. 2 Control variables}

As mentioned in Subsection 2.1, the CA bases its analysis principally on functionings and capabilities. As the main goal of this study is to provide new evidence about the effect of entrepreneurship on $\mathrm{HD}$, the analysis focuses on entrepreneurial activities by innovation and necessity as functionings. Likewise, it is necessary to include human capabilities indicators as control variables. According to Sen (1999), the capabilities people must have to do and be what they really desire depend on individual tastes and preferences. However, a group of basic capabilities exist; these can be understood as instrumental freedoms, which are associated with political freedoms, economic services, social opportunities, guaranteed transparency, and protective security.

In practice, the indicators of human capabilities are limited and few international organizations publish such information (Robeyns, 2017). In this study, the use of control variables related to human capabilities is conditioned by the availability of data. One of the basic human capabilities that have a measure is economic freedom, which is calculated by means of two different indexes created by the Heritage Foundation and the Fraser Institute. The use of one or the other index for a particular study depends principally on the period analyzed (Santiago, Fuinhas, \& Marques, 2018). To measure economic freedom, this study uses the Heritage Foundation Index, which has been widely used since its creation in 1995, as a valid measure of economic freedom (Bjornskov \& Foss, 2016; Goel, 2018; Goldsmith, 1995; Graafland \& Lous, 2018; Haan \& Sturm, 2000; Hanke \& Walters, 1997).

The Heritage Foundation defines economic liberty as the fundamental right of every human being to control his or her own work and property. Individuals are free to work, produce, consume, and invest in any way they wish. Governments allow work, capital, and goods to move freely, and refrain from exercising coercion beyond what is necessary to protect and maintain freedom (Miller, Kim, \& Roberts, 2019).

The Index of Economic Freedom (IEF) is measured by quantitative and qualitative indicators grouped into four categories: rule of law (property rights, governmental integrity, and judicial integrity); size of government (government spending, taxation, and financial health); normative efficiency (commercial freedom, freedom of labor, and monetary freedom); and open markets (freedom of trade, freedom of investment, and financial freedom). Each indicator has a scale from 0 to 100 . The overall score of a country is obtained by averaging the indicators, giving each one the same weight (Miller et al., 2019).

Taking into account that the IEF is an index composed of several indicators and that in its calculation method no evaluation is made of convergent validity, with reference to the consistency of its measurement, in this study, an evaluation of the reliability of this index is carried out using Cronbach's alpha, which is a good statistical measure of the reliability of scales (Ott, 2018). The result obtained is 0.8931 , indicating that the grouping of the indicators is valid, as it is greater than 0.7 (Bland \& Altman, 1997).

According to the World Bank (2013), the structure of the age of a population is valuable for analyzing the use of resources and formulating future policies and planning objectives with respect to infrastructure and development. Therefore, this study takes as the control variable the population aged 15-64 years old as a percentage of the total population. The data are obtained from the World Bank databank on development indicators. 


\subsection{Method}

For this study, four different samples are used, taking into account, as a first classification criterion, the availability of information on the independent variables, TEAIN and TEANEC, and then on human development, that is, the SPI and MHDI. The structure of the data from each sample and the method used are summarized in Table 1. Appendix B lists the counties analyzed.

Taking into account the availability of information, two evaluation techniques are used to test the proposed hypotheses. To evaluate the models with the SPI as a dependent variable, the pooled OLS technique is used. This technique is explained in Wooldridge (2009). In the evaluations in which the dependent variable is the MHDI, in addition to pooled OLS, the unbalanced panel data technique is applied. To generate consistent evaluations, countries with fewer than two observations are removed from the samples.

The proposed models for evaluation under the pooled OLS technique are as follows:

$$
\begin{aligned}
& H D_{i t}=\beta_{0}+\beta_{1} T_{E A I N}+\beta_{2} I E F_{i t}+\beta_{3} P O P_{i t}+e_{i t} \\
& H D_{i t}=\beta_{0}+\beta_{1} T E A N E C_{i t}+\beta_{2} I E F_{i t}+\beta_{3} P O P_{i t}+e_{i t}
\end{aligned}
$$

where $i$ refers to the $i$-th transversal unit (country); $t$ is time (year); $H D$ is a variable measuring human development (SPI, MHDI); TEAIN measures the rate of innovative entrepreneurial activity; TEANEC measures the rate of entrepreneurial activity by necessity; IEF measures economic freedom; and POP measures the population aged 15-64 years old.

According to Gujarati and Porter (2010), when information exists in the same cross-sectional units in time, it is possible to design models in which a combination of both types of data is used, which can be evaluated by means of panel data. Wooldridge (2009) argues that one of the main advantages of using the panel data technique is that it allows non-observable factors, which influence the dependent variable, to be classified into two types: those that are constant and those that vary with time. The same argument is put forward by Arellano and Bover (1990) and Plümper, Troeger, and Manow (2005).

Evaluations using panel data often present serial autocorrelation problems, heteroscedasticity, and even contemporary correlation (Canarella \& Gasparyan, 2008). According to Beck and Katz (1995), panel corrected standard errors (PCSE) allows the correction of the presence of serial autocorrelation, heteroscedasticity, and even contemporary correlation with precise evaluations of standard errors and with little or no loss of efficiency in comparison with other methods. Moreover, Beck and Katz (1995) suggest that the PCSE evaluation has the advantage that it can easily be used even when $T<N$, which is the case in the samples selected in this study. Thus, the results of the evaluations correspond to PCSE, which is represented in the following models:

$$
\begin{aligned}
& H D_{i t}=v_{i}+\beta_{1} T_{E A I N}+\beta_{2} I E F_{i t}+\beta_{3} P O P_{i t}+e_{i t} \\
& H D_{i t}=v_{i}+\beta_{1} T E A N E C_{i t}+\beta_{2} I E F_{i t}+\beta_{3} P O P_{i t}+e_{i t}
\end{aligned}
$$

where $i$ means the $i$-th transversal unit (country); $t$ is time (year); $H D$ is a variable measuring human development (SPI, MHDI); TEAIN measures the rate of innovative entrepreneurial activity; TEANEC measures the rate of entrepreneurial activity by necessity; IEF measures economic freedom; and $P O P$ measures the population aged 15-64 years old.

\section{Results}

Tables 2 and 3 summarize the descriptive statistics of the variables used (minimum and maximum values, average, and standard deviation). The maximum and minimum values indicate that the selection of the sample is unbiased owing to the heterogeneity of the countries studied with regard to their levels of entrepreneurship, social progress, and human development.

Tables 2 and 3 also show the bivariate correlation results, which are consistent with the proposed theory,

Table 1.

\section{Summary of samples used}

\begin{tabular}{cccccc}
\hline No & Period & Variables & Obs. & Countries & Method \\
\hline 1 & $2002-2015$ & MHDI, TEANEC, IEF, POP & 641 & 78 & Pooled OLS, PCSE \\
2 & $2014-2015$ & SPI, TEANEC, IEF, POP & 107 & 62 & Pooled OLS \\
3 & $2011-2017$ & MHDI, TEAIN, IEF, POP & 384 & 72 & Pooled OLS, PCSE \\
4 & $2014-2017$ & SPI, TEAIN, IEF, POP & 211 & 66 & Pooled OLS \\
\hline
\end{tabular}


providing initial evidence for the testing of the hypotheses. It is observed that a positive and significant correlation exists between the variables that measure human development, that is, the SPI and MHDI, and TEAIN, while the correlation between TEANEC and both the SPI and MHDI is negative and significant. The correlation between both the SPI and MHDI and the control variables (IEF and POP) is positive and significant.
Table 4 summarizes the regressions calculated by pooled OLS and PCSE. The results of the evaluations indicate for all cases that the independent variables jointly explain the variable dependent. Moreover, the results allow the verification of the proposed hypotheses, as described below.

Hypothesis 1 indicates that the contribution of innovative entrepreneurship to human development goes

Table 2.

\section{Descriptive statistics and correlation matrix: samples 1 and 2}

\begin{tabular}{lccccccccc}
\hline \multicolumn{1}{c}{ Variable } & No & Mean & Std. Dev. & Min. & Max. & $\mathbf{1}$ & $\mathbf{2}$ & $\mathbf{3}$ \\
\hline 1. MHDI & 641 & 80.76 & 9.95 & 45.25 & 94.55 & 1 & & & \\
2. SPI & 107 & 76.40 & 10.86 & 36.43 & 89.37 & $0.96^{* * *}$ & 1 & \\
3.TEANEC & 641 & 2.85 & 2.71 & 0.09 & 16.44 & $-0.67^{* * *}$ & $-0.60^{* * *}$ & 1 \\
4. IEF & 641 & 65.98 & 9.26 & 37.6 & 89.4 & $0.58^{* * *}$ & $0.65^{* * *}$ & $-0.42^{* * *}$ & 1 \\
5. POP & 641 & 66.34 & 4.24 & 47.68 & 85.64 & $0.41^{* * *}$ & 0.15 & $-0.43^{* * *}$ & $0.16^{* * *}$ \\
\hline Note ${ }^{* * *} \mathrm{P}<0.01 *^{* *} \mathrm{P}<0.05$ & & & & & & & &
\end{tabular}

Table 3.

Descriptive statistics and correlation matrix: samples 3 and 4

\begin{tabular}{|c|c|c|c|c|c|c|c|c|c|c|}
\hline Variable & No & Mean & Std. Dev. & Min. & Max. & 1 & 2 & 3 & 4 & 5 \\
\hline 1. MHDI & 384 & 81.33 & 10.12 & 43.65 & 94.95 & 1 & & & & \\
\hline 2. SPI & 211 & 75.55 & 11.77 & 36.43 & 90.03 & $0.96^{* * *}$ & 1 & & & \\
\hline 3. TEAIN & 384 & 26.27 & 10.47 & 0.76 & 58.07 & $0.34^{* * *}$ & $0.37^{* * *}$ & 1 & & \\
\hline 4.TEANEC & 282 & 3.19 & 2.6 & 0.2 & 16.44 & $-0.68^{* * *}$ & $-0.66^{* * *}$ & $-0.19^{* * *}$ & 1 & \\
\hline 5. $I E F$ & 384 & 65.9 & 9.02 & 40.3 & 89.4 & $0.55^{* * *}$ & $0.63^{* * *}$ & $0.39^{* * *}$ & $-0.46^{* * *}$ & 1 \\
\hline 6. $P O P$ & 384 & 66.39 & 4.73 & 48.83 & 85.64 & $0.35^{* * *}$ & $0.20^{* * *}$ & 0.03 & $-0.33^{* * *}$ & $0.16^{* * *}$ \\
\hline
\end{tabular}

Note. ${ }^{* *} \mathrm{P}<0.01 ;{ }^{* *} \mathrm{P}<0.05$.

Table 4.

\section{Regression analysis}

\begin{tabular}{|c|c|c|c|c|c|c|}
\hline \multirow{2}{*}{ Variable } & \multicolumn{3}{|c|}{ Pooled OLS } & \multicolumn{3}{|c|}{ PCSE } \\
\hline & IPS & IPS & MHDI & MHDI & MHDI & MHDI \\
\hline \multirow[t]{2}{*}{ TEAIN } & $0.16^{* *}$ & & $0.15^{* * *}$ & & $0.039^{* *}$ & \\
\hline & $(0.06)$ & & $(0.04)$ & & $(0.01)$ & \\
\hline \multirow[t]{2}{*}{ TEANEC } & & $-1.83^{* * *}$ & & $-1.57^{* * *}$ & & $-0.49^{* * *}$ \\
\hline & & $(0.34)$ & & $(0.11)$ & & $(0.08)$ \\
\hline \multirow[t]{2}{*}{$I E F$} & $0.71^{* * *}$ & $0.56^{* * *}$ & $0.49^{* * *}$ & $0.39^{* * *}$ & $0.49^{* * *}$ & $0.47^{* * *}$ \\
\hline & $(0.07)$ & $(0.09)$ & $(0.05)$ & $(0.03)$ & $(0.04)$ & $(0.03)$ \\
\hline \multirow[t]{2}{*}{$P O P$} & 0.24 & 0.19 & $0.58^{* * *}$ & $0.39^{* * *}$ & $0.5^{* * *}$ & $0.65^{* * *}$ \\
\hline & $(0.2)$ & $(0.35)$ & $(0.14)$ & $(0.08)$ & $(0.15)$ & $(0.1)$ \\
\hline \multirow[t]{2}{*}{ CONS } & 7.54 & 32.01 & 5.69 & $32.97^{* * *}$ & 13.64 & 5.98 \\
\hline & $(15.4)$ & $(27.25)$ & $(9.98)$ & $(6.92)$ & $(10.43)$ & $(7.25)$ \\
\hline $\mathrm{N}$ & 211 & 107 & 384 & 641 & 384 & 641 \\
\hline Groups & 66 & 62 & 78 & 78 & 72 & 78 \\
\hline Prob. $>F$ & 0 & 0 & 0 & 0 & & \\
\hline Chi2 & & & & & 147.87 & 396.64 \\
\hline Chi2 Prob. & & & & & 0 & 0 \\
\hline $\mathrm{R} 2$ & 0.42 & 0.57 & 0.39 & 0.58 & 0.96 & 0.96 \\
\hline
\end{tabular}

Note. ${ }^{* \star} \mathrm{P}<0.01 ;{ }^{* *} \mathrm{P}<0.05$; Standard error ( ). 
beyond the generation of monetary income, as it favors the expansion of capabilities so that people can lead the lives they really desire. The analyses in this study show that TEAIN has a positive impact on the improvement of quality of life in the dimensions measured by the SPI, that is, satisfaction of needs, foundations of wellbeing, and opportunities. Similarly, TEAIN positively affects educational levels and life expectancy, measured by the MHDI.

The results are aligned with the theoretical proposal that innovative entrepreneurship measured by the GEM is a functioning that, by its characteristics, positively favors the expansion of capabilities. This is because the person who performs it is driven to carry out this activity based on the detection of an opportunity that allows him or her to do what he or she really wants.

Similarly, Gries and Naudés proposal (2011) is corroborated, whereby opportunity entrepreneurship as a process implies the creation of a new company that enables the entrepreneur to satisfy his or her economic needs, need for status, and need for recognition, among others, and therefore helps him or her to lead the life he or she really desires. Furthermore, according the results obtained in this study opportunity entrepreneurship oriented toward innovative as a resource help to expand people's capabilities.

Hypothesis 2 proposes that necessity entrepreneurship restricts the expansion of human capabilities for people to lead the lives they really desire. The values calculated in all the regressions with TEANEC as an independent variable indicate that this variable is significant and has a negative relationship with the expansion of the capabilities associated with the dimensions measured by the SPI and MHDI.

Necessity entrepreneurship is a mechanism of self-employment (Reynolds et al., 2005). From the perspective of the CA, an activity that is performed as a means of subsistence is restrictive of human freedoms (Sen, 1999), as it limits agency and, consequently, is a functioning whose evaluation cannot go beyond the possibility of the entrepreneur obtaining an income that allows him or her to satisfy his or her basic needs (and probably those of his or her family nucleus).

These descriptions are corroborated in this study, at least in the dimensions measured by the MHDI and SPI. This is especially so in the dimensions of the MHDI, in which there is a time series of data consisting of 13 years with information from 78 countries, the use of which enables us to achieve much more robust results than those obtained with the SPI, indicating that TEANEC has no positive effect on either education level or on life expectancy in the countries studied. This result can be explained by the fact that necessity entrepreneurship in most cases is undertaken by people with low human capital (Poschke, 2013), and their activities are not enough to generate a positive effect on $\mathrm{HD}$, beyond guaranteeing subsistence.

The result obtained on the negative incidence of necessity entrepreneurship in the dimensions of human development measured by the MHDI and SPI is a novel contribution to research that has found that this type of entrepreneurial activity does not favor economic growth (Acs, 2006). Moreover, as necessity entrepreneurship is not chosen voluntarily, it can cause dissatisfaction in those who perform it (Harbi \& Grolleau, 2012) and negatively affect happiness (Binder \& Coad, 2016; Block et al., 2015).

In all the evaluations in this study, the variable that measures economic freedom (IEF) is, as expected, significant and its coefficients denote that it has a positive effect on the expansion of capabilities, at least in the dimensions measured by the MHDI and SPI. According to Miller et al. (2019), the social benefits of economic freedom extend far beyond the possibility of generating monetary income or reducing poverty. Thus, countries with higher levels of economic freedom enjoy higher levels of human development, as economic freedom places their societies on the road toward more opportunities in education, better medical care, and better standards of living for citizens.

\section{Conclusions, Limitations, and Policy Implications}

The results of this study contribute to theoretical research that attempts to explain the effects of entrepreneurship on society, as they extend far beyond the impact of entrepreneurial activity on economic growth. New evidence is presented of the influence of innovative entrepreneurship and entrepreneurship by necessity on human development.

The first conclusion is that the CA facilitates the understanding of how a human activity can positively affect quality of life, as this approach presents a wide vision of the necessary conditions to achieve development, where economic and non-economic resources constitute only a part of all the elements that must be considered to determine whether people lead the lives they really desire. 
This study concludes that innovation-oriented opportunity entrepreneurship, measured by the GEM in the countries listed in Appendix B, is a functioning, because it represents the realization of a human activity. Moreover, it allows people to be what they desire. People undertake this activity because they decide to do so spontaneously and their personal conversion factors, resources, and capabilities allow it. The result of the action is valued positively, because it contributes to the satisfaction of people's individual needs and favors the expansion of their capabilities. Similarly, innovative entrepreneurship constitutes a resource that allows the expansion of other people's capabilities.

The results of the models evaluated taking the SPI and MHDI as a measure of human development corroborate the previous conclusion, since innovative entrepreneurship has a positive effect on quality of life, at least in the dimensions measured by the SPI and the MHDI.

Unlike the premise of Gries and Naudé (2011), this study concludes that necessity entrepreneurship is a functioning, because it denotes the realization of a human activity. However, it has limited impact on the lives that people really desire, because it is a subsistence activity and limits agency and the expansion of human capabilities. This is corroborated by the results from the evaluations carried out in which TEANEC as an independent variable does not favor the expansion of capabilities in the dimensions measured by the MHDI and SPI.

The principal limitation of this study is the scarcity of secondary information that allows causality analysis through statistical techniques, such as that proposed by Granger; as well as the realization of evaluations through panel data with the SPI as a dependent variable, which would provide more evidence on the impact of entrepreneurship rates on a multi-dimensional measure of human development. Nevertheless, based on the results, our main policy recommendation is that public projects and programs to support entrepreneurship, beyond promoting self-employment, should promote opportunity entrepreneurship related to innovation.

From a practical standpoint, this study's results could be useful in designing policies supporting opportunity entrepreneurship, especially for innovation, because necessity entrepreneurship restricts human agency while its impact on people's quality of life is questionable. Therefore, it is necessary to reduce subsistence self-employment rates by expanding remunerated job offers. To promote innovative entrepreneurship, public programs could support nascent entrepreneurs to adopt and use ICT, as doing so helps to reduce both production and distribution costs.

Finally, concerning the methodological limitations, future research should continue to provide information on the impact of entrepreneurship on human development. To this end, multidimensional synthetic indexes on human development could be created with information on cities or regions to determine their relationship with the creation of new firms in specific territories. Future research could also analyze the impact of human development on entrepreneurship, in which the dependent variables correspond to types of entrepreneurship (innovation and necessity).

\section{References}

Acs, Z. J. (2006). How is entrepreneurship good for economic growth? Innovations: Technology, Governance, Globalization, 1(1), 97-107. doi: 10.1162/itgg.2006.1.1.97

Acs, Z. J., Audretsch, D. B., Braunerhjelm, P., \& Carlsson, B. (2012). Growth and entrepreneurship. Small Business Economics, 39(2), 289-300. doi: 10.1007/s11187-0109307-2

Acs, Z. J., \& Storey, D. (2004). Introduction: Entrepreneurship and economic development. Regional Studies, 38(8), 871877. doi: 10.1080/0034340042000280901

Acs, Z. J., \& Szerb, L. (2007). Entrepreneurship, economic growth and public policy. Small Business Economics, 28(23), 109-122. doi: 10.1007/s11187-006-9012-3

Alkire, S. (2005). Briefing note capability and functionings: Definition \& justification. Human Development and Capability Association, 1-6. Retrieved from http:// terpconnect.umd.edu/ dcrocker/Courses/Docs/Alkire\%20 $\% 20$ Capability $\% 20$ Functioning $\% 20$ Briefing $\% 20$ Note.pdf

Anand, P., Hunter, G., Carter, I., Dowding, K., Guala, F., $\&$ van Hees, M. (2009). The development of capability indicators. Journal of Human Development and Capabilities, 10(1), 125-152. doi: 10.1080/14649880802675366

Anand, S., \& Sen, A. (2000). Human development and economic sustainability. World Development, 28(12), 2029-2049. doi: 10.1016/S0305-750X(00)00071-1 
Aparicio, S., Urbano, D., \& Audretsch, D. (2016). Institutional factors, opportunity entrepreneurship and economic growth: Panel data evidence. Technological Forecasting and Social Change, 102, 45-61. doi: 10.1016/J. TECHFORE.2015.04.006

Arellano, M., \& Bover, O. (1990). La econometría de datos de panel. Investigaciones Económicas (Segunda Época), 14(1), 3-45. Retrieved from https://www.cemfi. es/ -arellano/arellano-bover-inv-econ-1990.pdf

Asandului, L., Iacobuta, A., \& Cautisanu, C. (2016). Modelling economic growth based on economic freedom and social progress. Ecsdev.Org. Retrieved from http:// ecsdev.org/ojs/index.php/ejsd/article/view/348

Audretsch, D. B. (2007). Entrepreneurship capital and economic growth. Oxford Review of Economic Policy, 23(1), 63-78. doi: 10.1093/oxrep/grm001

Audretsch, D. B., Bönte, W., \& Keilbach, M. (2008). Entrepreneurship capital and its impact on knowledge diffusion and economic performance. Journal of Business Venturing, 23(6), 687-698. doi: 10.1016/J. JBUSVENT.2008.01.006

Audretsch, D. B. (2012). Entrepreneurship research. Management Decision, 50(5), 755-764. https://doi. org/10.1108/00251741211227384

Baumol, W. J. (1990). Entrepreneurship: Productive, unproductive, and destructive. Journal of Political Economy, 98(5) Part. 1, 893-921. doi: 10.1086/261712

Beck, N., \& Katz, J. N. (1995). What to do (and not to do) with time-series cross-section data. American Political Science Review, 89(03), 634-647. doi: 10.2307/2082979

Binder, M., \& Coad, A. (2016). How satisfied are the selfemployed? A life domain view. Journal of Happiness Studies, 17(4), 1409-1433. doi: 10.1007/s10902-015-9650-8

Birch, D. L. (1981). Who creates jobs? The Public Interest, 65(Fall), 62-82. Retrieved from https://www.nationalaffairs. com/public_interest/detail/who-creates-jobs

Bjornskov, C., \& Foss, N. J. (2016). Institutions, entrepreneurship, and economic growth: What do we know and what do we still need to know? Academy of
Management Perspectives, 30(3), 292-315. doi: 10.5465/ amp.2015.0135

Bland, J. M., \& Altman, D. G. (1997). Cronbach's alpha. BMJ, 314(7080), 572. doi:10.1136/BMJ.314.7080.572

Block, J. H., Kohn, K., Miller, D., \& Ullrich, K. (2015). Necessity entrepreneurship and competitive strategy. Small Business Economics, 44(1), 37-54. doi: 10.1007/ s11187-014-9589-x

Borozan, D., Arneric, J., \& Coric, I. (2017). A comparative study of net entrepreneurial productivity in developed and post-transition economies. International Entrepreneurship and Management Journal, 13(3), 855-880. doi: 10.1007/ s11365-016-0427-2

Bosma, N., Litovsky, Y., Coduras, A., Seaman, J., Francis, J., Carmona, J., ... Wright, F. (2017). Gem Manual: Global entrepreneurship. London: London Bus. School. Retrieved from: https://www.gemconsortium.org/report/48360

Campos, H. M., Parellada, F. S., \& Palma, Y. (2012). Mapping the intellectual structure of entrepreneurship research: RBGN: Revista Brasileira de Gestâo de Négocios/ Review of Business Management, 14(42), 41-58. doi: 10.7819/rbgn.v14i42.958

Canarella, G., \& Gasparyan, A. (2008). New insights into executive compensation and firm performance. Managerial Finance, 34(8), 537-554. doi: 10.1108/03074350810874064

Carree, M., Van Stel, A., Thurik, R., \& Wennekers, S. (2007). The relationship between economic development and business ownership revisited. Entrepreneurship \& Regional Development, 19(3), 281-291. doi: $10.1080 / 08985620701296318$

Chambers, R. (1983). Rural development: Putting the last first. London; New York: Longman Scientific and Technical.

Costantini, V., \& Monni, S. (2008). Environment, human development and economic growth. Ecological Economics, 64(4), 867-880. doi: 10.1016/J.ECOLECON.2007.05.011

Dhahri, S., \& Omri, A. (2018). Entrepreneurship contribution to the three pillars of sustainable development: What does the evidence really say? World Development, 106, 64-77. doi: 10.1016/j.worlddev.2018.01.008 
Drèze, J., \& Sen, A. (2002). India: Development and participation. New York: OUP Oxford.

Frank, A. G. (1967). Capitalism and Underdevelopment in Latin America. New York: Monthly Review Press.

Fukuda-Parr, S. (2003). The human development paradigm: operationalizing Sen's ideas on capabilities. Feminist Economics, 9(2-3), 301-317. doi: 10.1080/1354570022000077980

Gnyawali, D. R., \& Fogel, D. S. (1994). Environments for entrepreneurship development: Key dimensions and research implications. Entrepreneurship: Theory \& Practice, 18(4), 43-62. doi: 10.1177/104225879401800403

Goel, R. K. (2018). Foreign direct investment and entrepreneurship: Gender differences across international economic freedom and taxation. Small Business Economics, 50(4), 887-897. doi: 10.1007/s11187-017-9914-2

Goldsmith, A. A. (1995). Democracy, property rights and economic growth. Journal of Development Studies, 32(2), 157-174. doi: 10.1080/00220389508422409

Graafland, J., \& Lous, B. (2018). Economic freedom, income inequality and life satisfaction in OECD countries. Journal of Happiness Studies, 19(7), 2071-2093. doi:10.1007/ s10902-017-9905-7

Gries, T., \& Naudé, W. (2011). Entrepreneurship and human development: A capability approach. Journal of Public Economics, 95(3-4), 216-224. doi:10.1016/j. jpubeco.2010.11.008

Gujarati, D. N., \& Porter, D. C. (2010). Econometría (5th ed.). Madrid: Ed. McGraw-Hill.

Haan, J. de, \& Sturm, J.-E. (2000). On the relationship between economic freedom and economic growth. European Journal of Political Economy, 16(2), 215-241. doi:10.1016/S0176-2680(99)00065-8

Hanke, S. H., \& Walters, S. J. K. (1997). Economic freedom, prosperity, and equality: A survey. Cato Journal, 17(2), 117-130.

Harbi, S. El, \& Grolleau, G. (2012). Does self-employment contribute to national happiness? The Journal of SocioEconomics, 41(5), 670-676. doi: 10.1016/j.socec.2012.06.001
Hartmann, D. (2014). Economic complexity and human development: How economic diversification and social networks affect human agency and welfare. New York: Routledge, Abingdon.

Hechavarria, D. M., \& Reynolds, P. D. (2009). Cultural norms $\&$ business start-ups: The impact of national values on opportunity and necessity entrepreneurs. International Entrepreneurship and Management Journal, 5(4), 417-437. doi: 10.1007/s11365-009-0115-6

Kleine, D. (2010). ICT4what? Using the choice framework to operationalise the capability approach to development. Journal of International Development, 22(5), 674-692. doi: 10.1002/jid.1719

Koellinger, P. D., \& Thurik, A. R. (2012). Entrepreneurship and the business cycle. Review of Economics and Statistics, 94(4), 1143-1156. doi: 10.1162/REST_a_00224

Kuznets, S. (1955). Economic growth and income inequality. The American Economic Review, 45(1), 1-28. Retrieved from http://www.jstor.org/stable/1811581

Levie, J., Autio, E., Acs, Z. J., \& Hart, M. (2014). Global entrepreneurship and institutions: An introduction. Small Business Economics, 42(3), 437-444. doi: 10.1007/ s11187-013-9516-6

Lo, C. C., Ash-Houchen, W., \& Gerling, H. M. (2017). The double-edged sword of gender equality: A cross-national study of crime victimization. International Criminal Justice Review, 27(4), 255-277. doi: 10.1177/1057567717700492

Mattedi, A. P., Bazanela, A. N., Jr., Santos, F. T. C. dos, \& Pereira, S. B. (2015). Desenvolvimento econômico, social e tecnológico: Sob uma perspectiva dos indicadores. RCH: Revista Ciências Humanas, 8(2), 101-116. Retrieved from https://www.rchunitau.com.br/index.php/rch/ article/view/284

Mayer, A., Haas, W., \& Wiedenhofer, D. (2017). How countries' resource use history matters for human wellbeing: An investigation of global patterns in cumulative material flows from 1950 to 2010. Ecological Economics, 134, 1-10. doi: 10.1016/J.ECOLECON.2016.11.017

Miller, T., Kim, A. B., \& Roberts, J. M. (2019). 2019 Index of Economic Freedom :25th anniversary edition. 
Retrieved from https://www.heritage.org/index/pdf/2019/ book/index_2019.pdf

Naudé, W., Amoros, J., \& Cristi, O. (2013). "Romanticizing penniless entrepreneurs?” The relationship between start-ups and human wellbeing across countries. ( $Z B W$, IZA Discussion Papers, No. 7547). Retrieved from https://www.econstor. eu/bitstream/10419/80527/1/766699846.pdf

Ott, J. (2018). Measuring economic freedom: Better without size of government. Social Indicators Research, 135(2), 479-498. doi: 10.1007/s11205-016-1508-x

Perényi, Á., \& Losoncz, M. (2018). A systematic review of international entrepreneurship special issue articles. Sustainability. doi:10.3390/su10103476

Plümper, T., Troeger, V. E., \& Manow, P. (2005). Panel data analysis in comparative politics: Linking method to theory. European Journal of Political Research, 44, 327-354. doi: 10.1111/j.1475-6765.2005.00230.x

Porter, M. E., Stern, S., \& Artavia Loría, R. (2013). Social Progress Index 2013. Washington, DC: Social Progress Imperative. Retrieved from http://www. competitividad.org.do/wp-content/uploads/2013/05/ SocialProgressIndex2013.pdf

Poschke, M. (2013). 'Entrepreneurs out of necessity': A snapshot. Applied Economics Letters, 20(7), 658-663. doi: 10.1080/13504851.2012.727968

Reynolds, P. D. (2017, Feb.). Enhancing understanding of entrepreneurial phenomena: Ethnographic opportunities in PSED and GEM assessments. Princeton Kauffman Conference 2017.

Reynolds, P. D., Bosma, N., Autio, E., Hunt, S., De Bono, N., Servais, I., ... Chin, N. (2005). Global entrepreneurship monitor: Data collection design and implementation 1998-2003. Small Business Economics, 24(3), 205-231. doi: $10.1007 / \mathrm{s} 11187-005-1980-1$

Robeyns, I. (2005). Selecting capabilities for quality of life measurement. Social Indicators Research, 74(1), 191 215. doi: 10.1007/s11205-005-6524-1

Robeyns, I. (2017). Wellbeing, freedom and social justice: The capability approach re-examined. Cambridge: Open Book Publishers.
Rosa, P., Kodithuwakku, S. S., \& Balunywa, W. (2008, December). Entrepreneurial motivation in developing countries: What does "necessity" and "opportunity" entrepreneurship really mean? Retrieved from https:// papers.ssrn.com/sol3/papers.cfm?abstract_id=1310913\#\#

Santiago, R., Fuinhas, J. A., \& Marques, A. C. (2018). The impact of globalization and economic freedom on economic growth: The case of the Latin America and Caribbean countries. Economic Change and Restructuring, 1-25. doi: 10.1007/s10644-018-9239-4

Schumpeter, J. A. (1939). The theory of economic development: An inquiry into profits, capital, credit, interest, and the business cycle. New York: McGraw-Hill.

Sen, A. (1998). Capital humano y capacidad humana. Cuadernos de Economía, 17(29), 67-72. Retrieved from: file://C:/Users/32229131885/Documents/Downloads/ Dialnet-CapitalHumanoYCapacidadHumana-4934956\%20 (1).pdf

Sen, A. (1999). Development as freedom. New York: Anchor Books.

Sen, A. (2005). Human rights and capabilities. Journal of Human Development, 6(2), 151-166. doi: 10.1080/14649880500120491

Shane, S., \& Venkataraman, S. (2000). The promise of entrepreneurship as a field of research. Academy of Management Review, 25(1), 217-226. doi: 10.5465/ AMR.2000.2791611

Stanojević, A., \& Benčina, J. (2018). The construction of an integrated and transparent index of wellbeing. Social Indicators Research, 1-21. doi: 10.1007/s11205-018-2016-y

Stern, S., Wares, A., \& Epner, T. (2017). Social progress index 2017: Methodology report. Retrieved from https://www. socialprogress.org/assets/downloads/resources/2017/2017Social-Progress-Index-Methodology.pdf

Stern, S., Wares, A., Orzell, S., \& O'Sullivan, P. (2014). Social Progress Index 2014: Methodological Report.. Retrieved from https://www.yumpu.com/en/document/read/46085246/ social-progress-index-2014-methodological-report

Stiglitz, J. E., Sen, A., \& Fitoussi, J.-P. (2009). Report by the Commission on the Measurement of Economic 
Performance and Social Progress. Retrieved from: http:// files.harmonywithnatureun.org/uploads/upload112.pdf

Sugden, R., \& Sen, A. (1986). Commodities and capabilities. The Economic Journal, 96(383), 820. doi: $10.2307 / 2232999$

Szabo, Z. K., \& Herman, E. (2012). Innovative entrepreneurship for economic development in EU. Procedia Economics and Finance, 3, 268-275. doi: 10.1016/ S2212-5671(12)00151-7

UNDP (1990). Human development report 1990. Retrieved from http://hdr.undp.org/sites/default/files/ reports/219/hdr_1990_en_complete_nostats.pdf

UNDP (2014). Human development report 2014: Sustaining human progress: Reducing vulnerabilities and building resilience. Retrieved from http://hdr.undp.org/ sites/default/files/hdr14-report-en-1.pdf

Urbano, D., \& Alvarez, C. (2014). Institutional dimensions and entrepreneurial activity: An international study. Small Business Economics, 42(4), 703-716. doi: 10.1007/ s11187-013-9523-7

Urbano, D., \& Aparicio, S. (2016). Entrepreneurship capital types and economic growth: International evidence. Technological Forecasting and Social Change, 102, 34-44. doi:10.1016/J.TECHFORE.2015.02.018
Urbano, D., Aparicio, S., \& Audretsch, D. (2018). Twenty-five years of research on institutions, entrepreneurship, and economic growth: What has been learned? Small Business Economics, 1-29. doi: 10.1007/s11187-018-0038-0

Urbano, D., Aparicio, S., \& Querol, V. (2016). Social progress orientation and innovative entrepreneurship: an international analysis. Journal of Evolutionary Economics, 26(5), 1033-1066. doi: 10.1007/s00191-016-0485-1

Van Hemmen, S., Alvarez, C., Peris-Ortiz, M., \& Urbano, D. (2015). Leadership styles and innovative entrepreneurship: An international study. Cybernetics and Systems, 46(3-4), 271-286. doi: 10.1080/01969722.2015.1012896

Wennekers, S., Van Wennekers, A., Thurik, R., \& Reynolds, P. D. (2005). Nascent entrepreneurship and the level of economic development. Small Business Economics, 24, 293-309. DOI 10.1007/s11187-005-1994-8

Wooldridge, J. M. (2009). La econometría introducción: Un enfoque moderno (4a ed.). México: Cengage Learning.

World Bank. (2013). World development indicators. Retrieved from http://documents.worldbank.org/curated/ pt/449421468331173478/pdf/768240PUB0EPI00IC0 0PUB0DATE04012013.pdf 


\section{APPENDIX A.}

Table A1.

COUNTRIES ANALIZED SAMPLES 1 and 2

\begin{tabular}{|c|c|c|c|c|c|c|c|}
\hline \multicolumn{4}{|c|}{ Sample 1} & \multicolumn{4}{|c|}{ Sample 2} \\
\hline No. & Country & No. & Country & No. & Country & No. & Country \\
\hline 1 & Algeria & 40 & Kazakhstan & 1 & Angola & 32 & Japan \\
\hline 2 & Angola & 41 & Latvia & 2 & Argentina & 33 & Kazakhstan \\
\hline 3 & Argentina & 42 & Lithuania & 3 & Australia & 34 & Latvia \\
\hline 4 & Australia & 43 & Luxembourg & 4 & Austria & 35 & Lithuania \\
\hline 5 & Austria & 44 & Macedonia & 5 & Barbados & 36 & Luxembourg \\
\hline 6 & Barbados & 45 & Malaysia & 6 & Belgium & 37 & Macedonia \\
\hline 7 & Belgium & 46 & Mexico & 7 & Bolivia & 38 & Malaysia \\
\hline 8 & Bolivia & 47 & Netherlands & 8 & Botswana & 39 & Mexico \\
\hline 9 & Bosnia & 48 & New Zealand & 9 & Brazil & 40 & Netherlands \\
\hline 10 & Botswana & 49 & Nigeria & 10 & Canada & 41 & Norway \\
\hline 11 & Brazil & 50 & Norway & 11 & Chile & 42 & Panama \\
\hline 12 & Canada & 51 & Pakistan & 12 & China & 43 & Peru \\
\hline 13 & Chile & 52 & Panama & 13 & Colombia & 44 & Philippines \\
\hline 14 & China & 53 & Peru & 14 & Costa Rica & 45 & Poland \\
\hline 15 & Colombia & 54 & Philippines & 15 & Croatia & 46 & Portugal \\
\hline 16 & Costa Rica & 55 & Poland & 16 & Denmark & 47 & Romania \\
\hline 17 & Croatia & 56 & Portugal & 17 & Ecuador & 48 & Russia \\
\hline 18 & Czech Republic & 57 & Romania & 18 & Egypt & 49 & Singapore \\
\hline 19 & Denmark & 58 & Russia & 19 & Estonia & 50 & Slovakia \\
\hline 20 & Dominican Republic & 59 & Singapore & 20 & Finland & 51 & Slovenia \\
\hline 21 & Ecuador & 60 & Slovakia & 21 & France & 52 & South Africa \\
\hline 22 & Egypt & 61 & Slovenia & 22 & Germany & 53 & South Korea \\
\hline 23 & Estonia & 62 & South Africa & 23 & Greece & 54 & Spain \\
\hline 24 & Finland & 63 & South Korea & 24 & Guatemala & 55 & Suriname \\
\hline 25 & France & 64 & Spain & 25 & Hungary & 56 & Sweden \\
\hline 26 & Germany & 65 & Suriname & 26 & India & 57 & Switzerland \\
\hline 27 & Ghana & 66 & Sweden & 27 & Indonesia & 58 & Thailand \\
\hline 28 & Greece & 67 & Switzerland & 28 & Iran & 59 & Tunisia \\
\hline 29 & Guatemala & 68 & Thailand & 29 & Ireland & 60 & United Kingdom \\
\hline 30 & Hungary & 69 & Trinidad \& Tobago & 30 & Israel & 61 & United States \\
\hline 31 & Iceland & 70 & Tunisia & 31 & Italy & 62 & Uruguay \\
\hline 32 & India & 71 & Turkey & & & & \\
\hline 33 & Indonesia & 72 & Uganda & & & & \\
\hline 34 & Iran & 73 & U. Arab Emirates & & & & \\
\hline 35 & Ireland & 74 & United Kingdom & & & & \\
\hline 36 & Israel & 75 & United States & & & & \\
\hline 37 & Italy & 76 & Uruguay & & & & \\
\hline 38 & Jamaica & 77 & Venezuela & & & & \\
\hline 39 & Japan & 78 & Zambia & & & & \\
\hline
\end{tabular}


Table A2.

\section{COUNTRIES ANALIZED SAMPLES 3 and 4}

\begin{tabular}{|c|c|c|c|c|c|c|c|}
\hline \multicolumn{4}{|c|}{ Sample 3} & \multicolumn{4}{|c|}{ Sample 4} \\
\hline No. & Country & No. & Country & No. & Country & No. & Country \\
\hline 1 & Algeria & 37 & Kazakhstan & 1 & Angola & 34 & Kazakhstan \\
\hline 2 & Angola & 38 & Latvia & 2 & Argentina & 35 & Latvia \\
\hline 3 & Argentina & 39 & Lebanon & 3 & Australia & 36 & Lebanon \\
\hline 4 & Australia & 40 & Lithuania & 4 & Austria & 37 & Lithuania \\
\hline 5 & Austria & 41 & Luxembourg & 5 & Barbados & 38 & Luxembourg \\
\hline 6 & Barbados & 42 & Macedonia & 6 & Belgium & 39 & Macedonia \\
\hline 7 & Belgium & 43 & Malaysia & 7 & Botswana & 40 & Malaysia \\
\hline 8 & Bosnia & 44 & Mexico & 8 & Brazil & 41 & Mexico \\
\hline 9 & Botswana & 45 & Morocco & 9 & Burkina Faso & 42 & Morocco \\
\hline 10 & Brazil & 46 & Netherlands & 10 & Cameroon & 43 & Netherlands \\
\hline 11 & Burkina Faso & 47 & Nigeria & 11 & Canada & 44 & Norway \\
\hline 12 & Cameroon & 48 & Norway & 12 & Chile & 45 & Panama \\
\hline 13 & Canada & 49 & Panama & 13 & China & 46 & Peru \\
\hline 14 & Chile & 50 & Peru & 14 & Colombia & 47 & Philippines \\
\hline 15 & China & 51 & Philippines & 15 & Croatia & 48 & Poland \\
\hline 16 & Colombia & 52 & Poland & 16 & Denmark & 49 & Portugal \\
\hline 17 & Croatia & 53 & Portugal & 17 & Ecuador & 50 & Qatar \\
\hline 18 & Denmark & 54 & Qatar & 18 & Egypt & 51 & Romania \\
\hline 19 & Ecuador & 55 & Romania & 19 & El Salvador & 52 & Russia \\
\hline 20 & Egypt & 56 & Russia & 20 & Estonia & 53 & Singapore \\
\hline 21 & El Salvador & 57 & Singapore & 21 & Finland & 54 & Slovakia \\
\hline 22 & Estonia & 58 & Slovakia & 22 & France & 55 & Slovenia \\
\hline 23 & Finland & 59 & Slovenia & 23 & Germany & 56 & South Africa \\
\hline 24 & France & 60 & South Africa & 24 & Greece & 57 & South Korea \\
\hline 25 & Germany & 61 & South Korea & 25 & Guatemala & 58 & Spain \\
\hline 26 & Greece & 62 & Spain & 26 & Hungary & 59 & Sweden \\
\hline 27 & Guatemala & 63 & Sweden & 27 & India & 60 & Switzerland \\
\hline 28 & Hungary & 64 & Switzerland & 28 & Indonesia & 61 & Thailand \\
\hline 29 & India & 65 & Thailand & 29 & Iran & 62 & Turkey \\
\hline 30 & Indonesia & 66 & Trinidad \& Tobago & 30 & Ireland & 63 & U. Arab Emirates \\
\hline 31 & Iran & 67 & Turkey & 31 & Israel & 64 & United Kingdom \\
\hline 32 & Ireland & 68 & Uganda & 32 & Italy & 65 & United States \\
\hline 33 & Israel & 69 & U. Arab Emirates & 33 & Japan & 66 & Uruguay \\
\hline 34 & Italy & 70 & United Kingdom & & & & \\
\hline 35 & Jamaica & 71 & United States & & & & \\
\hline 36 & Japan & 72 & Uruguay & & & & \\
\hline
\end{tabular}




\section{APPENDIX B.}

\section{Table B1.}

\section{STRUCTURE OF SOCIAL PROGRESS INDEX (SPI).}

\begin{tabular}{|c|c|c|}
\hline Dimensions & Components & Indicators \\
\hline \multirow{17}{*}{$\begin{array}{l}\text { Basic Human } \\
\text { Needs }\end{array}$} & Nutrition and basic medical & Undernourishment \\
\hline & care & Depth of food deficit \\
\hline & & Maternal mortality rate \\
\hline & & Child mortality rate \\
\hline & & Deaths from infectious diseases \\
\hline & Water and sanitation & Access to piped water \\
\hline & & Rural access to improved water source \\
\hline & & Access to improved sanitation facilities \\
\hline & Shelter & Availability of affordable housing \\
\hline & & Access to electricity \\
\hline & & Quality of electricity supply \\
\hline & & Household air pollution attributable deaths \\
\hline & Personal safety & Homicide rate \\
\hline & & Level of violent crime \\
\hline & & Perceived criminality \\
\hline & & Political terror \\
\hline & & Traffic deaths \\
\hline \multirow{14}{*}{$\begin{array}{l}\text { Foundations of } \\
\text { Wellbeing }\end{array}$} & Access to basic knowledge & Adult literacy rate \\
\hline & & Primary school enrolment \\
\hline & & Secondary school enrolment \\
\hline & & Gender parity in secondary enrolment \\
\hline & Health and wellness & Life expectancy at 60 \\
\hline & & Premature deaths from noncommunicable diseases \\
\hline & & Suicide rate \\
\hline & Access to information and & Mobile telephone subscriptions \\
\hline & communications & Internet users \\
\hline & & Press Freedom Index \\
\hline & Environmental quality & Wastewater treatment \\
\hline & & Outdoor air pollution attributable deaths \\
\hline & & Biodiversity and habitat \\
\hline & & Greenhouse gas emissions \\
\hline \multirow[t]{19}{*}{ Opportunity } & Personal rights & Political rights \\
\hline & & Freedom of expression \\
\hline & & Freedom of assembly \\
\hline & & Private property rights \\
\hline & Personal freedom and choice & Freedom over life choices \\
\hline & & Freedom of religion \\
\hline & & Early marriage \\
\hline & & Satisfied demand for contraception \\
\hline & & Corruption \\
\hline & Tolerance and inclusion & Tolerance for immigrants \\
\hline & & Tolerance for homosexuals \\
\hline & & Discrimination and violence against minorities \\
\hline & & Religious tolerance \\
\hline & & Community safety net \\
\hline & Access to advanced education & Years of tertiary schooling \\
\hline & & Women's average years in school \\
\hline & & Inequality in the attainment of education \\
\hline & & Globally ranked universities \\
\hline & & Percentage of tertiary students enrolled in globally ranked universities \\
\hline
\end{tabular}

Note. Source: Methodology Report, Social Progress Index 


\section{Authors:}

1. José Antonio Camacho Ballesta, PhD, University of Granada, Granada, Spain.

E-mail: jcamacho@ugr.es

\section{ORCID}

(1) 0000-0002-9786-5400

2. Bladimir José de la Hoz Rosales, $\mathrm{PhD}$, University of Magdalena, Santa Marta, Colombia.

E-mail: bdelahoz@unimagdalena.edu.com

ORCID

(1) 0000-0002-4900-9693

3. Ignacio Tamayo Torres, $\mathrm{PhD}$, University of Granada, Granada, Spain.

E-mail: igtamayo@ugr.es

ORCID

(1) 0000-0003-3823-6484

\section{Contribution of each author}

\begin{tabular}{lccc}
\hline \multicolumn{1}{c}{ Contribution } & José Ballesta & Bladimir Rosales & Ignacio Torres \\
\hline 1. Definition of research problem & $\sqrt{ }$ & $\sqrt{ }$ & $\sqrt{ }$ \\
2. Development of hypotheses or research questions (empirical studies) & $\sqrt{ }$ & $\sqrt{ }$ & $\sqrt{ }$ \\
3. Development of theoretical propositions (theoretical work) & $\sqrt{ }$ & $\sqrt{ }$ & $\sqrt{ }$ \\
4. Theoretical foundation/literature review & $\sqrt{ }$ & $\sqrt{ }$ \\
5. Definition of methodological procedures & $\sqrt{ }$ & $\sqrt{ }$ \\
6. Data collection & $\sqrt{ }$ & $\sqrt{ }$ \\
7. Statistical analysis & $\sqrt{ }$ & $\sqrt{ }$ \\
8. Analysis and interpretation of data & $\sqrt{ }$ & $\sqrt{ }$ \\
9. Critical revision of the manuscript & $\sqrt{ }$ & $\sqrt{ }$ \\
10. Manuscript writing & $\sqrt{ }$ & $\sqrt{ }$ \\
11. Other & $\sqrt{ }$ & $\sqrt{ }$ \\
\hline
\end{tabular}

